\title{
Update on bioagent therapy in sarcoidosis Vincent Cottin
}

\author{
Address: Hospices Civils de Lyon, Hôpital Louis Pradel, Service de Pneumologie - Centre de référence des maladies rares pulmonaires, \\ Université de Lyon, Université Lyon I, INRA, UMR754, IFR128, Lyon, France \\ Email: vincent.cottin@chu-lyon.fr
}

FI000 Medicine Reports 2010, 2:13 (doi:10.3410/M2-13)

The electronic version of this article is the complete one and can be found at: http://fl000.com/reports/medicine/content/2/I3

\begin{abstract}
Corticosteroids are still the cornerstone of treatment for patients with sarcoidosis requiring systemic therapy. However, alternative agents and especially methotrexate may be considered for patients with refractory disease or requiring prolonged treatment with intolerable side effects. Although bioagent therapies have hitherto not clearly demonstrated superior efficacy and safety over corticosteroids in pulmonary sarcoidosis, infliximab may modestly improve lung function in patients with active disease resistant to steroids. Further studies will be needed to assess both safety and efficacy of infliximab in pulmonary sarcoidosis. Infliximab may be considered in a limited number of patients with severe extrapulmonary systemic manifestations of sarcoidosis, with careful individual evaluation of the risk-benefit ratio.
\end{abstract}

\section{Introduction and context}

Treatment decision in sarcoidosis is based on the severity or duration of disease or both (e.g., acute or chronic sarcoidosis, the latter corresponding to active disease persisting beyond 5 years from the time of diagnosis) [1]. While no treatment is necessary in a majority of patients, corticosteroid therapy is the mainstay of treatment for those who require systemic therapy. Although the dose of steroids largely varies among centres and is based on experience rather than evidence, most clinicians use approximately $0.5 \mathrm{mg} / \mathrm{kg}$ per day (30-40 $\mathrm{mg}$ per day) of prednisone or equivalent as a starting daily dose in chronic sarcoidosis [2]. After maximum improvement has been achieved, corticosteroid therapy is slowly tapered to maintenance therapy (10-15 mg or approximately $0.25 \mathrm{mg} / \mathrm{kg}$ daily) in order to establish the minimal dose that controls disease activity; this requires regular reassessment of pulmonary symptoms, chest radiographs, and pulmonary function [2]. The disease may be considered refractory if improvement has been documented following $0.5 \mathrm{mg} / \mathrm{kg}$ per day prednisone treatment for at least 3-6 months.
Alternative agents may be used for patients with disease refractory to corticosteroid therapy (e.g., with symptoms not controlled or worsening despite adequate corticosteroid therapy), for those requiring long-term high-dose treatment for chronic disease, or for those who cannot tolerate corticosteroid side effects. When bioagent therapy is being considered, the decision analysis approach should include the risk of long-term corticosteroid therapy at the maintenance dose and that of potentially toxic alternative therapy. Corticosteroid dependence should not be considered a treatment failure that systematically requires steroid-sparing agents; indeed, a low-dose corticosteroid treatment when well tolerated may be superior to bioagent therapies, which may cause significant, albeit different, adverse events. Whether follow-up without therapy is possible or whether therapy is mandatory should be systematically re-evaluated when considering alternative therapy. Methotrexate $(10 \mathrm{mg} /$ week $)$ has demonstrated steroidsparing activity in patients with acute [3] and chronic [4] sarcoidosis, with a cumulative risk of hepatotoxicity, and is considered the first-choice alternative to 
corticosteroids; a detailed discussion of methotrexate therapy and other non-bioagent alternative drugs [1] is beyond the scope of this review. Long-term monitoring is required for both response to therapy and toxicity regardless of the drug used.

\section{Recent advances}

Two anti-tumour necrosis factor-alpha (TNF- $\alpha$ ) therapies have been evaluated in sarcoidosis (Tables 1 and 2). Two studies using etanercept failed to show a treatment benefit in patients with either progressive pulmonary disease, using a composite endpoint of dyspnea, pulmonary function, and chest radiograph [5], or methotrexate-resistant, corticosteroid-treated ocular sarcoidosis, using the steroid-sparing effect and global ocular assessment as an endpoint [6]. Both exploratory studies suffered significant methodological limitations, especially the absence of a control group [5] and small sample size [6]. Diffusion of etanercept into tissues, especially the vitreous, may also be limited [6]. Therefore, etanercept does not seem to be effective in most patients with chronic sarcoidosis.

In contrast, two retrospective series reported symptomatic improvement in most patients receiving infliximab $[7,8]$. Although the level of evidence was low, efficacy was suggested in patients with chronic multiorgan extrapulmonary disease, especially lupus pernio, uveitis, and neurosarcoidosis, refractory to oral corticosteroids or with intolerable side effects $[7,8]$. Infliximab was also shown to be beneficial in lupus pernio [9] and chronic inflammatory eye disease in sarcoidosis, including in patients who had not responded to etanercept [10].

Nineteen patients with chronic active pulmonary sarcoidosis (stage II-IV) who had received corticosteroids for at least 3 months with suboptimal response or intolerance were included in a randomised trial [11], and 13 of them received infliximab. No significant difference was observed between groups for the primary endpoint (i.e., the relative change in vital capacity 6 weeks after initiation of treatment). No change was found in the secondary endpoints, including radiologic changes, health-related quality of life, and dyspnea scores. However, the study was underpowered due to insufficient accrual. Although not significant, the change in vital capacity in treated patients was paralleled by a trend toward improved vital capacity in the subjects in the placebo group during the open-label treatment in the second phase of the study. Of note, one patient receiving infliximab had pneumonia, and another developed recurrent cellulitis.

In a larger phase II randomised controlled trial in 138 patients with stable chronic pulmonary sarcoidosis (radiographic stage II-III) [12], infliximab therapy in addition to a stable dose of background corticosteroids or immunosuppressive therapy or both was associated with a $2.5 \%$ mean increase in forced vital capacity at week 24 versus 0 in controls $(P=0.038)$. Post hoc analysis identified the subgroups that benefited the most from this therapy, including those with more severe disease. The clinical relevance of the modest and transitory improvement in lung function, though statistically significant, was unclear. No improvement was obtained in secondary endpoints. Patients with phase IV or cavitary sarcoidosis or both were not included. Evaluation of severity of extrapulmonary involvement used a new, non-validated tool [12], which may not adequately reflect clinical severity as required for decision analysis [13]. The small magnitude of improvement (with potential underestimation of the treatment effect [13]) may be partly due to selection bias, with exclusion of patients with the most severe disease $[13,14]$ and inclusion of patients with stable disease already receiving at least $10 \mathrm{mg} /$ day of prednisone.

The effectiveness of infliximab therapy in chronic granulomatous disease (such as sarcoidosis and Crohn's disease) has been hypothesised to be related to its mechanism of action, whereby it binds both free TNF- $\alpha$ and cell surface TNF- $\alpha$ (the latter being involved in complement-mediated cell lysis and antibody-dependent cell-mediated cytotoxicity as well as apoptosis induction of activated lymphocytes), in contrast to etanercept, which binds soluble but not surface molecules [15].

Table I. Available anti-tumour necrosis factor-alpha therapies

\begin{tabular}{llll}
\hline Drug & Mechanism of action & Route & Dosage \\
\hline Adalimumab & Humanised monoclonal anti- TNF- $\alpha$ antibody & Subcutaneous & $3-5 \mathrm{mg} / \mathrm{kg}$ every 2 weeks \\
Etanercept & $\begin{array}{l}\text { Fusion protein of ligand-binding domain of human TNF- } \alpha \text { receptor-I and } \\
\text { human Fc fraction of IgGI }\end{array}$ & Subcutaneous & $25 \mathrm{mg}$ twice weekly \\
Infliximab & Chimeric mouse/human monoclonal IgGI anti-TNF- $\alpha$ antibody & Intravenous & $3-5 \mathrm{mg} / \mathrm{kg}$, then 2 weeks later, then every \\
& & & $\mathrm{I}-2 \mathrm{months}$ \\
\hline
\end{tabular}

TNF- $\alpha$, tumour necrosis factor-alpha. 
Table 2. Summary of the main studies of anti-tumour necrosis factor-alpha therapy in sarcoidosis

\begin{tabular}{|c|c|c|c|c|c|}
\hline Reference & Drug & Design & Indication & Primary endpoint & Results and comments \\
\hline [5] & Etanercept & $\begin{array}{l}\text { Open-label, phase II, } 12 \\
\text { months; } \mathrm{n}=17\end{array}$ & $\begin{array}{l}\text { Progressive stage II-III lung } \\
\text { disease }\end{array}$ & Composite endpoint & $\begin{array}{l}\text { Early termination of study for } \\
\text { lack of efficacy } \\
\text { Nasopharyngeal plasmocytoma } \\
\text { and intestinal lymphoma } \\
\text { developed }\end{array}$ \\
\hline [6] & Etanercept & $\begin{array}{l}\text { Double-blind randomised } \\
\text { controlled trial, } 6 \text { months; } \\
\mathrm{n}=18\end{array}$ & $\begin{array}{l}\text { Ocular sarcoidosis with } \\
\text { ongoing inflammation in the } \\
\text { eyes } \\
\text { Methotrexate-resistant, } \\
\text { corticosteroid-dependent } \\
\text { disease }\end{array}$ & Corticosteroid-sparing effect & $\begin{array}{l}\text { Lack of steroid-sparing effect } \\
\text { Lack of ophthalmology global } \\
\text { improvement }\end{array}$ \\
\hline [8] & Infliximab & $\begin{array}{l}\text { Retrospective series, } \\
\text { infliximab } 5 \mathrm{mg} / \mathrm{kg} \text { at weeks } \\
0,2 \text { and } 6, \text { then every } \\
8 \text { weeks; } n=10\end{array}$ & $\begin{array}{l}\text { Patients with drug failure or } \\
\text { intolerable side effects } \\
\text { Indication of therapy } \\
\text { extrapulmonary (skin disease } \\
\text { in } 6 \text { of 10) }\end{array}$ & $\begin{array}{l}\text { Heterogeneous individual } \\
\text { retrospective clinical } \\
\text { assessment } \\
\text { Steroid-sparing effect }\end{array}$ & $\begin{array}{l}\text { Symptomatic improvement in } \\
9 \text { of } 10 \text { patients, objective } \\
\text { improvement in all } \\
10 \text { patients } \\
\text { Steroid-sparing effect obtained } \\
\text { Angioimmunoblastic } \\
\text { lymphoma developed }\end{array}$ \\
\hline [7] & Infliximab & $\begin{array}{l}\text { Retrospective series; } \\
\text { infliximab } 3 \mathrm{mg} / \mathrm{kg} \text { at weeks } 0 \text {, } \\
2,4,6,10 \text { and } 14 ; \mathrm{n}=12\end{array}$ & $\begin{array}{l}\text { Chronic multiorgan } \\
\text { sarcoidosis, refractory or } \\
\text { intolerant to corticosteroids } \\
\text { or alternative drugs }\end{array}$ & $\begin{array}{l}\text { Heterogeneous individual } \\
\text { retrospective assessment }\end{array}$ & $\begin{array}{l}\text { Some clinical or imaging } \\
\text { improvement in all patients } \\
\text { Low-quality evidence } \\
\text { Recurrence of symptoms upon } \\
\text { discontinuation of treatment } \\
\text { Myeloma developed }\end{array}$ \\
\hline$[11]$ & Infliximab & $\begin{array}{l}\text { Phase II, double-blind } \\
\text { randomised controlled trial, } \\
38 \text { weeks, } \mathrm{n}=19 \text {; infliximab } \\
5 \mathrm{mg} / \mathrm{kg} \text { or placebo at weeks } \\
0 \text { and } 2 \text {, then infliximab at } \\
\text { weeks } 6 \text { and } 14\end{array}$ & $\begin{array}{l}\text { Chronic active pulmonary } \\
\text { sarcoidosis, stage II-IV } \\
\text { VC } 50-80 \% \text { of predicted } \\
\text { Patients having received } \\
\text { corticosteroids for } \geq 3 \\
\text { months, with suboptimal } \\
\text { response or intolerance }\end{array}$ & $\begin{array}{l}\text { Mean relative change in } \mathrm{VC} \text { at } \\
\text { week } 6\end{array}$ & $\begin{array}{l}\text { Non-significant relative change } \\
\text { in VC ( }(15.2 \% \pm 9.9 \% \text { with } \\
\text { infliximab versus } \\
8.4 \% \pm 3.3 \% \text { with placebo, } \\
P=0.65) \\
\text { No change in secondary } \\
\text { endpoints } \\
19 \text { included patients ( } 42 \\
\text { planned); underpowered trial } \\
\text { One death possibly related to } \\
\text { infliximab }\end{array}$ \\
\hline$[12,14]$ & Infliximab & $\begin{array}{l}\text { Phase II, double-blind rando- } \\
\text { mised controlled trial; I:I:I } \\
\text { to receive placebo, infliximab } \\
3 \mathrm{mg} / \mathrm{kg} \text { or infliximab } 5 \mathrm{mg} / \mathrm{kg} \\
\text { at weeks } 0,2,6,12,18 \text { and } \\
24 ; \mathrm{n}=138\end{array}$ & $\begin{array}{l}\text { Chronic stable pulmonary } \\
\text { sarcoidosis, stage II-III } \\
\text { FVC } 50-85 \% \text { of predicted } \\
\text { Patients receiving } \geq 10 \mathrm{mg} / \text { day } \\
\text { of prednisone or immuno- } \\
\text { suppressive therapy or both } \\
68 \% \text { of patients with } \\
\text { extrapulmonary involvement }\end{array}$ & $\begin{array}{l}\text { Change in FVC at week } 24 \\
\text { Post hoc analysis of predefined } \\
\text { secondary endpoint ePOST }\end{array}$ & $\begin{array}{l}\text { FVC improvement by } 2.5 \% \text { at } \\
\text { week } 24 \text { versus } 0 \text { in controls } \\
(P=0.038) \\
\text { Post hoc analysis identified } \\
\text { subgroups that benefited most } \\
\text { from therapy } \\
\text { Significant improvement of } \\
\text { ePOST score at } 24 \text { weeks, not } \\
\text { maintained after treatment } \\
\text { discontinuation } \\
\text { Adverse events included } \\
\text { pneumonia ( } 4.4 \%) \text {, skin } \\
\text { squamous cell carcinoma and } \\
\text { epitheliod sarcoma }\end{array}$ \\
\hline
\end{tabular}

ePOST, extrapulmonary organ severity tool; FVC, forced vital capacity; VC, vital capacity.

Promising results have been reported in cases treated with the anti-TNF- $\alpha$ adalimumab $[16,17]$, and trials are currently being conducted (NCT00311246, NCT00274352). Of note, the paradoxical development of sarcoidosis has rarely been reported during treatment with all three available TNF- $\alpha$ antagonists, an event potentially linked to cytokine disequilibrium [18-24].

In view of the accumulated evidence, limitations of published trials using anti-TNF- $\alpha$ antibodies suffer from several flaws, including an inadequate target that does not include membrane-bound TNF- $\alpha[5,6]$, inadequate retrospective design $[7,8]$, inadequate patient population with stable rather than progressive pulmonary disease [12], and insufficient sample size and power [11].

Trials are under way using golimumab, a fully human monoclonal antibody directed against TNF- $\alpha$ (NCT00955279); ustekinumab, a human antiinterleukin-12/interleukin-23 monoclonal antibody 
(NCT00955279); and abatacept, a fusion protein composed of the Fc fraction of human immunoglobulin G1 fused to the extracellular domain of cytotoxic T-lymphocyte antigen 4 (NCT00739960), an inhibitory molecule expressed on the surface of helper T cells. One report of improvement using rituximab has been published [25], although sarcoidosis is not a B celldriven or autoimmune disease.

\section{Implications for clinical practice}

Available evidence does not support the use of etanercept in sarcoidosis. The experience with adalimumab is too limited to draw conclusions in sarcoidosis. Infliximab may improve lung function in patients with active pulmonary sarcoidosis resistant to steroids, but with modest and clinically debatable benefit. Long-term studies will be needed to assess both safety and efficacy of infliximab in patients with intractable active disease, in whom corticosteroids are either not effective or not tolerated. Anti-TNF- $\alpha$ therapy should be further evaluated in patients with progressive disease, who may be more apt to benefit from therapy [12], as suggested by a preliminary underpowered negative study [11]. However, severity scores $[14,26]$ need to be validated prospectively with regard to prognosis.

Pending further evidence, corticosteroids remain the cornerstone of therapy in sarcoidosis. The use of infliximab in sarcoidosis can be discussed on an individual basis with careful evaluation of the riskbenefit ratio, and should preferably be considered in the context of randomised clinical trials. Infliximab may be used in patients with progressive disease refractory to corticosteroids, especially in the context of lupus pernio, intractable uveitis, or neurosarcoidosis. Infliximab is unlikely to provide significant benefit in patients with severe but stable stage IV pulmonary disease. Current risk-benefit analysis suggests that infliximab be used preferably as third-line therapy (after failure of methotrexate as second-line therapy). In such a situation, it is preferable that low-dose corticosteroids be continued in association with infliximab. There are no clinical data to support the concomitant use of methotrexate and infliximab in sarcoidosis, although the possibility of blocking antibodies to infliximab during treatment prompts some clinicians to use concomitant low-dose methotrexate. Methotrexate should be preferred to bioagent therapy in patients with intolerable side effects of corticosteroids and who require maintenance of therapy; infliximab should currently not be considered the steroid-sparing agent of choice in sarcoidosis.

Although TNF- $\alpha$ antagonists appear to be relatively safe (with a safety profile quite distinct from that of systemic corticosteroids), concerns that anti-TNF- $\alpha$ therapy might increase the risk of tumour may limit the use of these agents in the future, and careful evaluation of this potential risk is warranted. Anti-TNF- $\alpha$ therapy increases the risk of infection, including tuberculosis [27]. Infusion reactions are usually mild [28]. Human antichimeric antibody may develop in patients receiving repeated infusion [29,30], with a controversial role in hypersensitivity reactions; the combination of infliximab with low-dose methotrexate may be used to limit the risk of antibody formation.

Given the well-proven effectiveness of corticosteroids in the treatment of active pulmonary sarcoidosis, newer therapies must demonstrate superior efficacy and safety in order to become the standard of care [11]. This has not been demonstrated for bioagent therapy, with the notable exception of infliximab in a limited number of patients with disease intractable with corticosteroids, especially those with severe systemic manifestations.

\section{Abbreviation}

TNF- $\alpha$, tumour necrosis factor-alpha.

\section{Competing interests}

The authors declare that they have no competing interests.

\section{Acknowledgements}

Financial support was provided by the University of Lyon. The author is indebted to Jean-François Cordier (Lyon, France) for critical review of the manuscript.

\section{References}

I. Baughman RP, Costabel U, du Bois RM: Treatment of sarcoidosis. Clin Chest Med 2008, 29:533-48, ix-x.

2. Judson MA: An approach to the treatment of pulmonary sarcoidosis with corticosteroids: the six phases of treatment. Chest 1999, I I5: I 158-65.

3. Baughman RP, Winget DB, Lower EE: Methotrexate is steroid sparing in acute sarcoidosis: results of a double blind, randomized trial. Sarcoidosis Vasc Diffuse Lung Dis 2000, I 7:60-6.

4. Lower EE, Baughman RP: Prolonged use of methotrexate for sarcoidosis. Arch Intern Med 1995, I 55:846-5I.

5. Utz JP, Limper AH, Kalra S, Specks U, Scott JP, Vuk-Pavlovic Z, Schroeder DR: Etanercept for the treatment of stage II and III progressive pulmonary sarcoidosis. Chest 2003, I 24:I77-85.

6. Baughman RP, Lower EE, Bradley DA, Raymond LA, Kaufman A: Etanercept for refractory ocular sarcoidosis: results of a double-blind randomized trial. Chest 2005, I28:1062-47.

7. Saleh S, Ghodsian S, Yakimova V, Henderson J, Sharma OP: Effectiveness of infliximab in treating selected patients with sarcoidosis. Respir Med 2006, 100:2053-9.

8. Doty JD, Mazur JE, Judson MA: Treatment of sarcoidosis with infliximab. Chest 2005, I27:1064-7I.

9. Stagaki E, Mountford WK, Lackland DT, Judson MA: The treatment of lupus pernio: results of 116 treatment courses in 54 patients. Chest 2009, I35:468-76. 
10. Baughman RP, Bradley DA, Lower EE: Infliximab in chronic ocular inflammation. Int J Clin Pharmacol Ther 2005, 43:7-II.

II. Rossman MD, Newman LS, Baughman RP, Teirstein A, Weinberger SE, Miller W Jr, Sands BE: A double-blinded, randomized, placebo-controlled trial of infliximab in subjects with active pulmonary sarcoidosis. Sarcoidosis Vasc Diffuse Lung Dis 2006, 23:20I-8.

12. Baughman RP, Drent M, Kavuru M, Judson MA, Costabel U, du Bois R, Albera C, Brutsche M, Davis G, Donohue JF, Muller-Quernheim J, Schlenker-Herceg R, Flavin S, Lo KH, Oemar B, Barnathan ES: Infliximab therapy in patients with chronic sarcoidosis and pulmonary involvement. Am J Respir Crit Care Med 2006, I 74:795802.

FI000 Factor 4.8 Must Read

Evaluated by Fernando Martinez 24 Oct 2006, Jay H Ryu 05 Dec 2006

13. Wells AU: Infliximab in extrapulmonary sarcoidosis: tantalising but inconclusive. Eur Respir J 2008, 3 I: I I 48-9.

14. Judson MA, Baughman RP, Costabel U, Flavin S, Lo KH, Kavuru MS, Drent M: Efficacy of infliximab in extrapulmonary sarcoidosis: results from a randomised trial. Eur Respir J 2008, 3 I: I I89-96.

15. Van den Brande JM, Braat $H$, van den Brink GR, Versteeg $H H$, Bauer CA, Hoedemaeker I, van Montfrans C, Hommes DW, Peppelenbosch MP, van Deventer SJ: Infliximab but not etanercept induces apoptosis in lamina propria T-lymphocytes from patients with Crohn's disease. Gastroenterology 2003, I 24: | 774-85.

16. Thielen AM, Barde C, Saurat JH, Laffitte E: Refractory chronic cutaneous sarcoidosis responsive to dose escalation of TNFalpha antagonists. Dermatology 2009, 21 9:59-62.

17. Marnane M, Lynch T, Scott J, Stack J, Kelly PJ: Steroid-unresponsive neurosarcoidosis successfully treated with adalimumab. J Neurol 2009, 256:139-40.

18. Massara A, Cavazzini L, La Corte R, Trotta F: Sarcoidosis appearing during anti-tumor necrosis factor alpha therapy: a new "class effect" paradoxical phenomenon. Two case reports and literature review. Semin Arthritis Rheum 2010, 39:313-9.

19. Metyas SK, Tadros RM, Arkfeld DG: Adalimumab-induced noncaseating granuloma in the bone marrow of a patient being treated for rheumatoid arthritis. Rheumatol Int 2009, 29:437-9.
20. Callejas-Rubio JL, Ortego-Centeno N, Lopez-Perez L, Benticuaga MN: Treatment of therapy-resistant sarcoidosis with adalimumab. Clin Rheumatol 2006, 25:596-7.

21. Almodovar R, Izquierdo M, Zarco P, Javier Quiros F, Mazzucchelli R, Steen B: Pulmonary sarcoidosis in a patient with ankylosing spondylitis treated with infliximab. Clin Exp Rheumatol 2007, 25:99-101.

22. González-López MA, Blanco R, González-Vela MC, FernándezLlaca $H$, Rodríguez-Valverde V: Development of sarcoidosis during etanercept therapy. Arthritis Rheum 2006, 55:8I7-20.

23. Ishiguro T, Takayanagi N, Kurashima K, Matsushita A, Harasawa K, Yoneda K, Tsuchiya N, Miyahara Y, Yamaguchi S, Yano R, Tokunaga D, Saito H, Ubukata M, Yanagisawa T, Sugita Y, Kawabata Y: Development of sarcoidosis during etanercept therapy. Intern Med 2008, 47:1021-5.

24. Verschueren K, Van Essche E, Verschueren P, Taelman V, Westhovens R: Development of sarcoidosis in etanercepttreated rheumatoid arthritis patients. Clin Rheumatol 2007, 26:1969-7|.

FI000 Factor 6.0 Must Read

Evaluated by Tetsuo Shiohara 2I Jul 2008

25. Belkhou A, Younsi R, El Bouchti I, El Hassani S: Rituximab as a treatment alternative in sarcoidosis. Joint Bone Spine 2008 , 75:5II-2.

26. Wasfi YS, Rose CS, Murphy JR, Silveira LJ, Grutters JC, Inoue Y, Judson MA, Maier LA: A new tool to assess sarcoidosis severity. Chest 2006, I29:। 234-45.

27. Brassard P, Kezouh A, Suissa S: Antirheumatic drugs and the risk of tuberculosis. Clin Infect Dis 2006, 43:717-22.

28. Vultaggio A, Matucci A, Parronchi P, Rossi O, Palandri F, Romagnani S, Maggi E: Safety and tolerability of infliximab therapy: suggestions and criticisms based on wide clinical experience. Int J Immunopathol Pharmacol 2008, 21:367-74.

29. Miele E, Markowitz JE, Mamula P, Baldassano RN: Human antichimeric antibody in children and young adults with inflammatory bowel disease receiving infliximab. J Pediatr Gastroenterol Nutr 2004, 38:502-8.

30. van der Bijl AE, Breedveld FC, Antoni CE, Kalden JR, Kary S, Burmester GR, Beckmann C, Unnebrink K, Kupper H: An openlabel pilot study of the effectiveness of adalimumab in patients with rheumatoid arthritis and previous infliximab treatment: relationship to reasons for failure and antiinfliximab antibody status. Clin Rheumatol 2008, 27:1021-8. 